\title{
Behavioral Patterns and Professional Attributes of Filipino Subject Teachers in Relation to Students' Performance
}

\author{
Gregg O. Siat ${ }^{1}$
}

${ }^{1}$ Biliran Province State University, Naval, Biliran Philippines

Received: November 15, 2021

Revised: December 16, 2021

Accepted: December 31, 2021

\begin{abstract}
The study generally aimed to determine the behavioral patterns and professional attributes of Filipino subject teachers in relation to students' performance in selected secondary schools in Area III, Leyte Division. A standardized questionnaire was used to gather information from the Filipino subject teachers regarding their behavioral patterns and professional attributes in relation to the students' performance. The data were analysed and interpreted with the aid of the statistical tool. Weighted mean was used in determining the behavioral patterns of Filipino subject teachers. As a result of the survey conducted data gathered were the following: Professional attributes of Filipino subject teachers in terms of educational attainment, majority had earned MA units; as to teaching experience, they have rendered 10-14 years; and relative to in-service training, majority of them attended at the division level. With regards to the behavioral patterns of Filipino subject teachers as evaluated by the students, it was perceived good. Further, on the level of students' performance, they were rated satisfactory performance.
\end{abstract}

Keywords: Filipino Subject Teachers, Professional Attributes, Students' Performance

\section{Introduction}

The teachers develop the young minds of individuals and serve as a model in actions and in words. They are considered as individuals who assist the youth to become assets members in the society. And above all, they are creators of quality citizenry. Teaching is a complicated task. It requires understanding and unfathomable patience in dealing with students in order to attain quality education (Gram et al., 2013). It does not only depend on the teacher's mental abilities but also with their behavioral patterns shown during the discharge of their duties (James \& Skrupskelis, 1983).

Valle (2006) mentioned that good teaching revolve around curriculum preparation, effective instruction, and appropriate assessment or evaluation. It is of paramount important that the teacher should understand the philosophical, psychological and societal objectives of education and rate the following character traits: honesty, generosity, congeniality, tactfulness, friendliness, cooperativeness, high moral standard, and high ethical and professional standard (Morrison et al., 2019). In addition, he should have a strong interest in people, and should always be in search for better ways of doing his job and preventing the disciplinary problems that could interfere with normal and classroom progress (Dajotoy, 2002).

Although teachers develop good behavioral patterns, they need also to grow professionally for them to become competent enough in the field of education (Lacambra, 2005). Since change must start with the teacher, they are expected to upgrade their professional attributes through attending seminars, training and post-graduate studies to imbibe new knowledge, skills and techniques, attitudes and values that would greatly contribute the efficiency of students' performance (Palma, 2002; Tyler, 2013).

Today, many students complain what the teachers are doing inside the classroom which is common among many public secondary schools. According to some students, there are teachers 
who possess undesirable behaviour which hinder the students learning interest and contribute a negative effect on their performance (Sagay, 2002). If this dilemma will not be solved, the quality of education in the country which is the potent instrument of the youth's bright future will be hampered. In effect, educators should find ways and means to eradicate or at least lessen the existence of such problems; thus, this urge the researcher to conduct they current study to find out the behavioral patterns and professional attributes of Filipino subject teachers in selected secondary schools in Area III, Leyte Division as it relates to the level of students' performance in Filipino. Objectives of the Study, Specifically, the study sought to answer the following; (1) Determine the professional attributes of Filipino subject teachers in selected secondary schools in Area III, Leyte Division in terms of: (a) educational attainment; (b) teaching experience; and (c) in-service training; (2) Find out the behavioral patterns of Filipino subject teachers in selected secondary schools in Area III, Leyte Division; (3) Determine the level of students' performance in selected secondary schools in Area III, Leyte Division

\section{Methods}

The researcher employed the descriptive research method. The researcher believes the method as the most appropriate because it can obtain facts that looked into the prevailing problems existing during the present period. A standardized questionnaire was used to gather the needed data. Data were analysed and summarized using weighted mean as the primarily tool for the data analysis.

\section{Results and Discussion}

\section{Professional attributes of Filipino subject teachers}

This study determined the professional attributes of Filipino subject teachers as presented on Tables 1-3. Educational attainment. Table 1 presents the educational attainment of Filipino subject teachers.

Table 1. Educational attainment of Filipino subject teachers

\begin{tabular}{|l|c|c|}
\hline \multicolumn{1}{|c|}{ Educational attainment } & $\mathrm{f}$ & $\%$ \\
\hline Baccalaureate Degree & 3 & 33.33 \\
\hline Baccalaureate Degree with Masteral units & 6 & 66.67 \\
\hline Masteral Degree holder & 0 & 0 \\
\hline MA with Doctoral units & 0 & 0 \\
\hline Doctorate Total & 0 & 0 \\
\hline \multicolumn{1}{|c|}{ Ton.00 } \\
\hline
\end{tabular}

The table clearly shows that the Filipino subject teachers need to upgrade their profession in order to improve instruction. Teaching experience. The table that follows presents the teaching experience of Filipino subject teachers.

Table 2. Teaching Experience of Filipino subject teachers

\begin{tabular}{|c|c|c|c|}
\hline Teaching experience & f & $\%$ & Description \\
\hline Below 5 years & 2 & 22.22 & Amateur \\
\hline 5-9 years & 2 & 22.22 & Postulant \\
\hline 10-14 years & 4 & 44.45 & Novice \\
\hline 15-19 years & 1 & 11.11 & Junior \\
\hline Above 20 years & 0 & 0 & Senior \\
\hline Total & $\mathbf{9}$ & $\mathbf{1 0 0 . 0 0}$ & \\
\hline
\end{tabular}


As reflected on the table, results implies that most of the Filipino subject teachers were novices in the service. In-service training. Shown on Table 3 is the in-service training attended by Filipino subject teachers

Table 3. In-service training of Filipino subject teachers

\begin{tabular}{|c|c|c|}
\hline Levels attended & f & $\%$ \\
\hline District level & 1 & 11.11 \\
\hline Division level & 5 & 55.56 \\
\hline Regional level & 2 & 22.22 \\
\hline National level & 1 & 11.11 \\
\hline International level & 0 & 0 \\
\hline Total & $\mathbf{9}$ & $\mathbf{1 0 0 . 0 0}$ \\
\hline
\end{tabular}

The results on Table 3 reveals that Filipino subject teachers need more training that would contribute to an improved students' performance.

\section{Behavioral Patterns of Filipino subject teachers}

Table 4 presents the evaluation of students on the behavioral patterns of Filipino subject teachers which is categorized into five.

Table 4. Students' Evaluation on the Behavioral Patterns of Filipino subject teachers

\begin{tabular}{|c|c|c|}
\hline Behavioral Patterns & Weighted Mean & Interpretation \\
\hline \multicolumn{3}{|l|}{ 1. Humility } \\
\hline 1.1 Encourage self-understanding. & 3.5 & Very Good \\
\hline 1.2 Polite even to his/her students. & 2.9 & Good \\
\hline $\begin{array}{l}1.3 \text { Encourages students to ask questions } \\
\text { and perceptions. }\end{array}$ & 3.6 & Very Good \\
\hline 1.4 Show deep concern to students. & 3.3 & Good \\
\hline 1.5 Has a good sense of humor. & 3.4 & Good \\
\hline AWM & 3.3 & Good \\
\hline \multicolumn{3}{|l|}{ 2. Refinement } \\
\hline $\begin{array}{l}2.1 \quad \text { Encourage continuing creative } \\
\text { expression. }\end{array}$ & 3.3 & Good \\
\hline $\begin{array}{l}2.2 \text { Demonstrates good grooming, poise, } \\
\text { and refinement of voice. }\end{array}$ & 2.6 & Fair \\
\hline 2.3 Is cheerful and always smiling. & 3.2 & Good \\
\hline 2.4 Enters the room quietly. & 3.5 & Good \\
\hline 2.5 Shows good taste in acting. & 3.1 & Good \\
\hline AWM & 3.1 & Good \\
\hline \multicolumn{3}{|l|}{ 3. Sociability } \\
\hline 3.1 Deals with people in cordial manner. & 3.8 & Very Good \\
\hline $\begin{array}{l}3.2 \text { Helps the students to perceive } \\
\text { meaningful relationship. }\end{array}$ & 3.8 & Very Good \\
\hline 3.3 Is courteous and friendly. & 3.7 & Very Good \\
\hline $\begin{array}{l}3.4 \quad \text { Makes a special effort to promote } \\
\text { good feelings of students. }\end{array}$ & 3.3 & Good \\
\hline $\begin{array}{l}3.5 \text { Encourages social activities that } \\
\text { build friendly among students. }\end{array}$ & 3.6 & Very Good \\
\hline AWM & 3.6 & Very Good \\
\hline 4. Consideration & & \\
\hline
\end{tabular}




\begin{tabular}{|c|c|c|}
\hline $\begin{array}{l}\text { 4.1 Gives full consideration to other } \\
\text { ideas, feelings, values and suggestions. }\end{array}$ & 3.3 & Good \\
\hline $\begin{array}{l}4.2 \text { Motivates the students by giving } \\
\text { praise for what is worth praising. }\end{array}$ & 3.8 & Very Good \\
\hline 4.3 Is considerate. & 2.6 & Fair \\
\hline $\begin{array}{l}4.4 \text { Understands the weaknesses of } \\
\text { students. }\end{array}$ & 3.4 & Very Good \\
\hline $\begin{array}{l}4.5 \text { Takes pain not to hurt the feelings of } \\
\text { others. }\end{array}$ & 3.8 & Very Good \\
\hline AWM & 3.4 & Very Good \\
\hline \multicolumn{3}{|l|}{ 5. Reliability } \\
\hline 5.1 Is consistent in judgement. & 2.8 & Good \\
\hline 5.2 Starts and ends the class on time. & 3.3 & Good \\
\hline $\begin{array}{l}5.3 \text { Shows sincerity and honesty in } \\
\text { dealing with students. }\end{array}$ & 3.5 & Very Good \\
\hline $\begin{array}{l}5.4 \text { Is accommodating and does not get } \\
\text { tired. }\end{array}$ & 3.2 & Good \\
\hline 5.5 Is punctual in reporting to classes. & 3.5 & Very Good \\
\hline AWM & 3.3 & Good \\
\hline$\overline{\text { OAWM }}$ & 3.3 & Good \\
\hline
\end{tabular}

Based on students' evaluation on the behavioral patterns of Filipino subject teachers, it is implicated that the teacher's behaviour can greatly affect the level of students' performance in Fiipino.

\section{Level of Students' Performance}

Table 5 presents the data on the level of students' performance in Filipino subject.

Table 5. Level of Students' Performance

\begin{tabular}{|c|c|c|}
\hline Grade level & Weighted Mean & Interpretation \\
\hline Grade 7 & 79.93 & Slightly Satisfactory Performance \\
\hline Grade 8 & 80.33 & Satisfactory Performance \\
\hline Grade 9 & 82.07 & Satisfactory Performance \\
\hline Grade 10 & 81.71 & Satisfactory Performance \\
\hline Total & 81.01 & Satisfactory Performance \\
\hline
\end{tabular}

The result in Table 5 implies that Filipino subject teachers are trying their best to perform their task as responsibilities as expected for the betterment of the leaners

\section{Conclusion}

Based on the findings of the study it is concluded that the behavioral patterns and professional attributes of Filipino subject teachers affect the level of students' performance in Filipino as manifested on student grades.

From the findings and conclusions drawn, the following recommendations were made; (1) Since we are aiming for quality education, it is therefore a need to all teachers particularly the Filipino subject teachers to grow professionally by enrolling graduate studies to answer the demands of the learners; (2) School heads must send Filipino subject teachers to trainings, seminars and conferences to update their profession so that they can adopt the current trends and innovations in attaining quality education; (3) School heads should monitor their teachers regularly for them to perform their task as expected and to improve students' performance; (4) Filipino subject teachers should maintain good behavioral patterns among students that would 
serve as their model in words and in deeds for they play a vital role in the attainment of good scholastic achievements; (5) A replication of this study in some schools within the division will give valid basis for generalizations and conclusions.

\section{References}

Dajotoy, E. D. (2002). Training Needs of Elementary Teachers in Almeria District: Basis for a Proposed In-Service Training Program.

Gram, M., Jæger, K., Liu, J., Qing, L., \& Wu, X. (2013). Chinese students making sense of problem-based learning and Western teaching-pitfalls and coping strategies. Teaching in Higher Education, 18(7), 761-772.

James, W., \& Skrupskelis, I. K. (1983). Talks to Teachers on Psychology and to Students on Some of Life's Ideals (Vol. 12). Harvard University Press.

Lacambra, L. M. (2005). How to Become an Outstanding Teacher". The Modern Teacher, Vol. XLIX, No. 7, December 2005.

Morrison, G. R., Ross, S. J., Morrison, J. R., \& Kalman, H. K. (2019). Designing effective instruction. John Wiley \& Sons.

Palma, J. C. (2002). Curriculum Development System”, Manila, National Book Store, Inc.

Sagay, T. C. (2002). The Teacher as a Role Model”, The Modern Teacher. (7).

Tyler, R. W. (2013). Basic principles of curriculum and instruction. University of Chicago press.

Valle, G. R. (2021). Narratives of place: critical reflections on place-making in the curriculum of environmental studies and sciences (ESS). Journal of Environmental Studies and Sciences, 11(1), 130-138. 